\title{
Die literêr-historiese lees van 'n teks
}

D J Human

(Universiteit van Pretoria)

\section{ABSTRACT}

\section{The literary historical reading of a text}

The discussion on methodology in the South African exegetical and hermeneutical debate has not been completed yet. Several contributions during the past six years have kept this debate alive. Nevertheless, the duration of the discussion has brought growth and more understanding for different viewpoints and approaches.

The aim of this article is to argue that both literary and historical aspects in the reading of any Old Testament text are important. Although it is not the only text approach, it proposes the literary-historical reading of texts is a comprehensive way to expose and understand Biblical texts.

\section{INLEIDING}

Die gesprek rondom "metode" in die Suid-Afrikaanse eksegetiese en hermeneutiese debat het nog lank nie opgedroog nie. Verskeie gepreksgenote het die afgelope ses jaar entoesiasties aan die diskussie deelgeneem ${ }^{1}$. Alhoewel daar vlak by die einde van die millenium nie naastenby eenstemmigheid oor die meeste sake bestaan nie, bring die duur van die gesprek geleidelik meer insig. By die individuele eksegeet, wat hom toenemend in die meer-perspektiwiese en sogenaamde "post-moderne" denke inleef, groei daar 'n vryheid om Bybelse tekste vanuit verkillende invalshoeke te lees.

Die debat self is intens. Ondersteuners van elke benadering, interpretasierigting of invalshoek op die metodiek van eksegese wil hul "produk" bekendstel. Natuurlik is dit reg so. Vir die leser moet dit oortuigend gestel word waarom hy/sy die teks op 'n bepaalde manier moet benader en ontleed. Soms gaan staan die leser agter die teks; soms is hy/sy binne in die teks; en natuurlik bevind hy/sy hom/haar altyd voor die teks met sy "bril".

In die lig van hierdie gesprek wil ek graag my eie invalshoek op die lees van veral die Ou-Testamentiese tekste ter tafel lê. Of dit nou heeltemaal nuut is, is ek nie so seker nie. My siening word gekleur deur die "bril" van my eie agtergrond, dit wil sê teologiese, filosofiese, konfessio- 
nele, wetenskapsteoretiese (en ander) voorveronderstellings. Die artikel het nie ten doel om die debat op te som of 'n "checklist" te maak om die "metode" met die meeste regmerkies aan te beveel nie. Veeleerder is dit om deur die debat heen tot die formulering van 'n eie verstaan en standpunt te kom.

\section{2 'N VERSKEIDENHEID VAN BENADERINGS}

Die Ou-Testamentiese tekste is literêr-gestolde geskiedenisgebeure wat deur verskeie teologies geïnterpreteerde Schichten in (meer of minder) verskillende kontekste tot selfstandige tekseenhede ontwikkel het. Om hierdie tekste vanuit 'n retrospektiewe blik te ontleed, het eksegete in die verlede 'n verskeidenheid van metodes en eksegetiese benaderings aangewend ${ }^{2}$.

Die vertrekpunte van hierdie benaderings kan opsommenderwys gereduseer word tot die historiese gebeure of teologiese idees agter die teks, die outeur(s) deur wie die teks geskryf of gemeenskap aan wie die tekst(e) gerig is, die teks self asook die leser ${ }^{3}$. Hieruit is dit dan nie moeilik nie om die vernaamste benaderings tot Ou-Testamentiese eksegese te reduseer tot die histories-kritiese benaderings, die struktuur-analitiese benaderings asook die resepsie-teoretiese benadering.

Met ' $n$ lang ontwikkelingsgeskiedenis en sy wortels diep in die Aufklärung gegrond, neem die histories-kritiese metodes ${ }^{4}$ die historiese gebeure of teologiese idees agter die Ou-Testamentiese teks as vertrekpunt vir eksegese. Hierdie benadering met sy verskillende fasette is 'n geldige metode om vrae rondom die ontstaan en ontwikkeling van die teks en sy interpretasie te probeer beantwoord. Op 'n diakroniese wyse word die historiese aspekte van 'n teks aangespreek.

Die tekortkominge van die histories-kritiese metode om alle vrae rondom die teks en sy struktuur bevredigend te beantwoord, het stimulus aan die ontstaan en ontwikkeling van teks- en struktuur-georiënteerde benaderings verleen. Soms word ook daarna verwys as die teksimmanente benadering, 'n "close reading", die narratiewe of literêre lees van die teks.

$\mathrm{Na}$ die Eerste Wêreldoorlog het die teksimmanente benaderings momentum begin kry. Ferdinand de Saussure se bydrae, naamlik, dat taal gestruktureerd is, asook dat 'n teks sinkroniese en diakroniese aspekte bevat, het die weg vir die analise van die Ou Testament as literêre en outonome kunswerk gebaan. Sodoende kon struktuur-analitiese metodes met die klem op die sinkroniese aspekte van die teks voortaan tot die rykdom van veelkleurige eksegetiese perspektiewe bydra. 
Miskien moet ons sê dat die ontwikkeling en bedryf van hierdie benadering die afgelope twee dekades hoogty onder Suid-Afrikaanse eksegete van die Ou Testament gevier het. Dit was 'n tydperk waar eksegete hul greep op die teks binne sy breër konteks wou verstewig. Deels in reaksie op die fundmentalistiese "prooftext" benadering in veral die Afrikaanse kerke; deels omdat dit binne die tydsgees van die tweede helfde van die tweede millenium vir mense 'n vaster greep op die bedryf van teologie gegee het; en deels uit reaksie teen die sogenaamde "onsekerhede" waarmee die histories kritiese benadering die gelowige leser en kerkganger gekonfronteer het. Verder staan dit nie los van die filosofiese strominge en eksegetiese ontwikkelinge binne Europa en die Amerika's nie. Ook nie alle eksegete het hierdie benadering op dieselfde manier beskou en bedryf nie.

Die resepsie-teoretiese benaderings analiseer die teks vanuit die oogpunt van die leser of ontvanger in die kommunikasieproses. Met die onderskeid tussen die geïmpliseerde en ander lesers ${ }^{5}$ word die ontvanger se rol in hierdie metode by die verstaansproses beklemtoon. As die jongste gespreksgenoot tot die debat rondom die metodiek van eksegese, vervul die resepsieteorie in sy verhouding tot ander eksegetiese metodes 'n aanvullende of komplementêre funksie ${ }^{6}$. Dit beklemtoon die rol wat die leser, sy/haar voorveronderstellings asook kontekstuele gesitueerdheid in die leesproses van die teks speel. Hierdie "bril" baan die weg vir byvoorbeeld die sosiologiese, psigologiese ${ }^{7}$, antropologiese ${ }^{8}$, ideologiese ${ }^{9}$, politieke ${ }^{10}$, feministiese ${ }^{11}$, swart teologiese ${ }^{12}$ of bevrydings-teologiese lees van tekste.

\section{SUID-AFRIKAANSE KONTEKS}

\subsection{Inleiding}

Binne die Suid-Afrikaanse konteks is die gesprek rondom die bogenoemde eksegetiese benaderings oorbekend. 'n Herhaling van rolspelers en hulle standpunte is onnodig. Hierdie gesprek vertoon plek-plek selfs tekens van oorverhitting (en uitbranding) sodat daar gewaak moet word om nie meer oor metodiek as 'n middel tot 'n doel in plaas van die doel self - dit wil sê die lees van die teks - te besin nie. Metode mag nie bo die leesproses van die teks verhef word nie.

Vir my word dit toenemend 'n vraag of daar verder van "metode" of "metodes" in die eksegetiese en hermeneutiese debat gepraat moet word. Dit skep die indruk van 'n vasgestelde of voorgeskrewe leespatroon - 'n "metode" om by die betekenis uit te kom.

Vir die "post-moderne" denker is so 'n voorgeskrewe lees van tekste om verskeie redes onaanvaarbaar. Sou die debat nie daardeur gedien 
word wanneer ons eerder van invalshoeke of bepaalde perspektiewe op die teks praat nie? 'n Bepaalde invalshoek opn die lees van 'n teks belig tog net bepaalde betekenismoontlikhede. Ons lees van tekste bly tog 'n proses wat deur verskillende aspekte agter die teks, in die teks en voor die teks beïnvloed word. Die bybelleser wil verseker blootgestel word aan die vele perspektiewe op die Ou Testament wanneer hy/sy binne talle kontekste die betekenis van die teks wil begryp.

\subsection{Pioniers-en baanbrekerswerk}

Baanbrekerswerk en bydraes wat veral F E Deist, J A Loader en W S Prinsloo tot die gesprek rondom metodiek van eksegese gelewer het, verdien besondere vermelding13. In reaksie hierop het verskeie navorsers komplementêre en raffinerende werk gelewer ${ }^{14}$. J H le Roux evalueer die Suid-Afrikaanse konteks deur dit te beskryf as 'n "Story of two ways"15. Hy meen Suid-Afrikaanse eksegete volg hetsy die historiese (diakroniese) of die teksimmanente (sinkroniese) benadering tot teksanalise. Op sy analise was daar ook reaksie ${ }^{16}$.

Dit is duidelik dat nie een van die bogenoemde eksegetiese benaderings die monopolie op teksanalise mag besit nie. Die verabsolutering van enige een alleen sal tot die vereensydiging en verarming van eksegetiese navorsingsresultate in die algemeen bydra.

Sowel die histories-kritiese as struktuur-analitiese metodes hou die gevaar in om positiwisties en subjektief toegepas te word ${ }^{17}$. Albei vertoon voorts 'n komplementêre karakter vanweë die samevoeging van verskillende metodefasette. Dit vra dus die vernuf en gebalanseerde oordeelsvermoë van elke eksegeet om sowel die diakroniese as sinkroniese aspekte by die teksanalise met mekaar in gesprek te laat tree. Sowel die historiese as literêre aspekte moet mekaar aanvul om die verskillende dimensies van die teks se veelkleurigheid na vore te bring.

\subsection{Noodsaak van 'n literêre lees}

Sowel narratiewe as poëtiese tekste beskik oor hul eie literêre sleutels om ontsluit te word. As voorbeeld kan ons poëtiese tekste as voorbeld neem. Die invloed van die literatuurwetenskap ${ }^{18}$ asook die toenemende navorsing om die wese van die sogenaamde "klassieke Hebreeuse poësie" te definieer, lewer 'n toenemende bydrae tot die vermeerdering van verskillende perspektiewe op Ou-Testamentiese poësie-tekste. 'n Gebrek aan eensgesindheid rondom feitlik alle aspekte van die Hebreeuse poësie verleen aan interpretasiemoontlikhede egter 'n ruim speelveld.

In die verlede is die invalshoek op die wese van Hebreeuse poësie hoofsaaklik vanuit twee blikpunte benader. Op voetspoor van Robert 
Lowth is die parallelismus membrorum as uitstaande kenmerk van poësie beskou en as bepalend vir die verstaan daarvan veronderstel ${ }^{19}$. Hierdie tradisionele siening verstaan die parallelisme as twee binêre versreëls met sintaktiese en semantiese ooreenstemminge. 'n Tweede invalshoek waar die ritme van die poësie as uitstaande kenmerk van Hebreeus geïdentifiseer word, het die metrum 'n belangrike voorveronderstelling vir die verstaan van die teks gemaak. Beide hierdie benaderings is egter problematies en omstrede.

In reaksie op hierdie parallelistiese en metriese benaderings bring die bydrae van $\mathrm{T}$ Collins nuwe insigte. Met sy beklemtoning van die sintaksis en woordorde in die versreël, onderskei hy vier basiese sinstipes in die Hebreeuse poësie ${ }^{20}$. Of alle Hebreeuse literatuur egter in hierdie sinstipes ingedeel sou kon word, kan na my oordeel bevraagteken word.

Die verset teen die tradisionele siening oor parallelisme is ook by $\mathrm{J}$ L Kugel te bespeur ${ }^{21}$. Met sy hoë waardering vir die die versreël, onderskei hy twee parallelle vershelftes wat deur 'n caesura geskei word as bepalende kenmerk van Hebreeuse poësie. Die tweede vershelfte bevat sowel retrospektiewe as prospektiewe kwaliteite, sodat die herhalende gedagte 'n emfatiese kakrakter verkry22.

'n Varsheid oor die denke rondom parallelisme word ook by A Berlin aangetref ${ }^{23}$. By haar word die poëtiese funksie van die parallelisme beskryf in terme van 'n ekwivalensie waarin terseldertyd 'n mate van kontras opgesluit lê. Vir haar beteken dit dat 'n parallelisme in sowel een versreël as binne 'n samehang van 'n hoeveelheid versreëls aangetref kan word.

Die Hebreeuse ritmiek of metrum is totaal omstrede 24 . Standpunte wissel vanaf ' $n$ algehele ontkenning 25 van die bestaan daarvan in Hebreeuse poësie tot die kliniese tel van konsonante ${ }^{26}$ of lettergrepe ${ }^{27}$ om konstante ritme-patrone in poëtiese tekste bloot te lê. Die "garstige Grabe" in ons kennis en taalaanvoeling van antieke Hebreeus, verhoed egter die vaslegging van eenvormige of algemeen aanvaarbare taalreëls om klemtone ter wille van metriese patrone met sekerheid te identifiseer.

Ten spyte van hierdie onsekerheid, kan selfs by die mees subjektiewe identifisering van metriese patrone, groter of kleiner afwykings binne strofe- of sinsverband aangetoon word. Dit vervul 'n aksentuerende funksie binne die teksstruktuur wat vir die semantiese analise verdere implikasies het. Sodoende vervul metrum byvoorbeeld 'n belangrike rol op die klankvlak van teksanalise.

Alhoewel parallelisme 'n belangrike poëtiese beginsel van die Hebreeuse digkuns is en metrum op die klankvlak van teksanalise 'n bedui- 
dende funksie vervul, is beide nie die enigste kenmerke van die Hebreeuse digkuns nie. Die monopolie wat enige een van hierdie twee op die verstaan van Hebreeuse poësie mag hou, sou 'n ontkenning van die talle ander stylfigure en poëtiese beginsels op verskeie vlakke van teksanalise beteken.

Pogings wat 'n omvattende benadering tot die aard van Hebreeuse poësie wou gee, is herkenbaar in die arbeid van M O'Connor, G Wanke, W G E Watson en L Alonso Schökel ${ }^{28}$. O'Connor ${ }^{29}$ het veral sintaktiese, metriese en parallelistiese elemente gekombineer. Dit het die analise op woord-, versreël- en strukturele vlak tot gevolg gehad het. Wanke ${ }^{30}$ betrek die aspekte wat op "Laut-, Wort-, Satz- und Textebene" betrekking het, terwyl Watson ${ }^{31}$ se metode ook 'n komprehensiewe karakter vertoon wat die teks se literêre boustene omvattend ontsluit.

Navorsing vanaf die laat sewentiger jare bevestig dus dat die aard van Hebreeuse poësie slegs met 'n komprehensiewe benadering ontsluit behoort te word. Selfs die ontwikkeling van die retoriese benadering tot die lees van die Ou Testament dui in hierdie rigting 32 . Alhoewel dit nie die enigste invalshoeke op die verstaan van 'n teks is nie, behoort hierdie insigte by die ontleding van enige Ou Testamentiese teks ernstig geneem en verreken te word.

\subsection{Noodsaak van 'n historiese lees}

So belangrik as wat die literêre lees van Ou Testamentiese tekste is, so belangrik is die historiese lees en verstaan daarvan. Bybelse tekste het nie alleen in bepaalde historiese kontekste ontstaan nie, maar dit het in daaropvolgende kontekste funksioneer. Tekste is herhaaldelik herinterpreteer en geaktualiseer in die verskillende groei- en ontwikkelingsfases. Op hierdie manier het die sogenaamde "oorspronklike" historiese ontstaansituasies toenemend vervaag en verduister. Wat oorspronklik gebeur het en wat die presiese historiese omstandighede agter die tekste is, kan moeilik vasgestel en gerekonstrueer word. Die beoefening van dissiplines soos tekskritiek, oorleweringskritiek, redaksiekritiek asook Gattungkritiek vir die bepaling van tekste se Sitz(e) im Leben bevestig dit.

Dit is waar dat Suid Afrika die Aufklärung gemis het ${ }^{33}$ en dat daar 'n gebrekkige historiese bewussyn ${ }^{34}$ in die ontleding van tekste binne SuidAfrikaanse konteks bestaan. Maar om die stelling te veralgemeen en op alle eksegete van toepassing te maak, sou ook nie billik wees nie. Miskien kan ons beweer dat die historiese lees van tekste in Suid-Afrika in die algemeen baie swak ontwikkeld is. Daarvoor kan net die Ou Testamentiese wetenskap in Suid Afrika self blameer word. Maar dit moet reggestel word. Eksegete moet toenemend bewus word van die teks se historiese bedding en uitleg. 
Historiese aspekte van enige Ou Testamentiese teks lê op verskillende vlakke. Afgesien van die geskiedenis of religionsgeschichtliche agtergrond waarteen tekste gelees kan word, vertoon die teks self verskillende historiese dimensies. 'n Teks het nie alleen 'n historiese proses van groei ondergaan nie, maar 'n enkele "finale teks" vir baie Skrifgedeeltes bestaan eenvoudig nie. Die finale teks moet deur die eksegeet geskep of totstand gebring word. Uit talle tekstradisies maak die eksegeet deur tekskritiese ingrepe 'n keuse vir 'n verstaanbare teks. Byvoegings en veranderings van verskillende tradente, verander die veronderstelde Sitz(e) im Leben van "Israel se geskiedenis" agter die teks telkens.

Wanneer 'n eksegeet die teks begin analiseer, doen hy/sy dit met 'n bepaalde konsep van "Israel se geskiedenis". Hierdie analise begin dus met 'n bepaalde historiese vertrekpunt - 'n historiese voorveronderstelling. Namate die eksegeet 'n teks lees en verstaan, kan veranderinge aan die bestaande "geskiedenis"-konsep aangebring word. Sodoende gaan die historiese interpretasieproses nie alleen voort nie, maar die teks word vanuit bepaalde historiese bedding(e) verstaan.

'n Geskiedeniskonsep van Israel val ook nie uit die lug nie. Verantwoordelik teksanaliste konstrueer hierdie beeld met behulp van (onder andere) Bybeltekste. Die konsep bly egter 'n rekonstruksie. Daarom kan die Bybelstudent aan die begin van sy/haar tekslesing 'n "naiewe" keuse maak vir die voorstelling van byvoorbeeld $M$ Noth ${ }^{35}$ geskiedenis van Israel of $\mathrm{R}$ Albertz ${ }^{36}, \mathrm{~K}$ van der Toorn ${ }^{37}$ of $\mathrm{J}$ de Moor $^{38}$ se godsdiens-historiese voorstellings. Hierdie prentjie kan die eksegeet daarna met die voortgaande lees van tekste self verander of totaal nuut improviseer. Dié geskiedenis "prentjie" funksioneer as 'n hermeneutiese sleutel wat die brug vir die teks se toepassing na die hedendaagse konteks slaan.

Om die historiese dimensies van die teks by eksegese te verreken, bly dus allernoodsaaklik. Saam met die literêre lees van enige Ou Testamentiese Bybelgedeelte is die historiese lees daarvan ononderhandelbaar.

\section{4 'N EIE BENADERING}

\subsection{Inleiding}

Die Suid-Afrikaanse gesprek rondom die metodiek van eksegese het 'n aantal waardevolle gesigspunte na vore gebring. Binne enige formulering van 'n eie benadering om 'n teks te eksegetiseer, behoort kennis daarvan geneem te word. Die vernaamste winspunte wat egter daaruit voortvloei, is die volgende: 
- dat dié metode van die analise van Hebreeuse tekste nie bestaan nie. Ruimte moet gelaat word vir die beoefening van verskeie metodes en benaderings ${ }^{39}$, afhangende van die vrae wat aan 'n teks gestel word of die teks se gewilligheid om deur 'n bepaalde metode aangespreek te word;

- om eenstemmigheid oor die metodiek van eksegese te verwag is om die grense van teologiese fantasering te oorskry en perspektiewe op die Hebreeuse teks in te perk. By die gebrek aan eenstemmigheid moet nie 'n krisis beleef word nie, maar die beginsel van verskeidenheid - hoe eensydig dit soms ook mag wees - moet die invalshoek op die ontplooiing van enige Ou-Testamentiese teks se veelkleurigheid wees;

- dat 'n metode soms die karakter van 'n komprehensiewe benadering kan vertoon, moet toegegee word ${ }^{40}$;

- sinkroniese en diakroniese fasette van die teks moet as komplementêre gespreksgenote van mekaar funksioneer en ontleed word. Dit geskied met die verdere veronderstelling dat elke eksegeet die teks met sy/haar eie "bril” benader en eksegetiseer;

- elke eksegeet moet met die erkenning van sy eie paradigma, dit wil sê sy eie teologiese en konfessionele agtergrond asook sy subjektiewe voorkeure, sy eie metodologiese vertrekpunte motiveer.

Met 'n komprehensiewe uitgangspunt tot teksanalise sou ek my invalshoek (metode?) as literêr-histories kan tipeer. Dit beteken dat die tekste aan die hand van sowel literêre as historiese gesigspunte ontleed moet word. Sinkronie en diakronie word sodoende komplementêre gespreksgenote. Aan die sinkroniese gestalte van die teks word egter metodologies (of prosesmatig) 'n werksprioriteit toegeken. Tog is dit moeilik om te sê of die teks eers literêr of histories bewerk word. Die teksanalise vind dan met 'n histories-bepaalde historiese voorverstaan plaas. Vanuit hierdie perspektief het die eksegese 'n historiese vertrekpunt.

In die daaropvolgende ontleding van diakroniese perspektiewe sal die literêre funksionering van historiese gesigspunte 'n vername bousteen van die eksegetiese proses vorm. In hierdie opsig is die aanduiding literêr binne die literêr-historiese benadering 'n rigtinggewende Chiffre om 
werksprioriteit aan die sinkroniese analise van die teks toe te ken. Hieruit word dit duidelik dat gesigspunte van die Vormanalise asook die Tradisiekritiek van die vernaamste bene is waarop teksanalise rus.

\subsection{Aspekte van die eksegetiese proses}

Om die Ou Testamentiese tekste te verstaan en te ontleed, moet die tekste tog gelees word. Jy moet die teks begin lees. Selfs die konsep oor Israel se geskiedenis, waarmee die eksegeet tekste begin lees, word hoofsaaklik deur duiders in die Ou Testament self bepaal. Die eksegeet moet dus sy/ haar greep op die teks nie prysgee nie. Alle meganismes om die teks te lees en te verstaan moet in takt gehou word.

Die lees van die teks is ook 'n proses. Sinkroniese en diakroniese aspekte moet by teksinterpretasie vervloei. Die teks kry betekenis namate die eksegeet die teks van alle kante intens "bekyk".

Aspekte van die leesproses hoef nie altyd dieselfde te wees nie. Om die teks te verstaan hoef ons nie elke keer 'n "checklist" van eksegetiese stappe deur te werk nie. Die soort literatuur bepaal meermaals watter aspekte meer aandag as ander moet geniet. Ook die eksegeet se gegewe konteks, sy hermeneutiese en filosofiese "bril" asook sy/haar vermoë om die Ou Testamentiese tekste te kan lees, bepaal die eksegeet se leesproses. Hoe minder vensters die eksegeet op die teks oopmaak, des te minder perspektiewe verkry hy/sy op die teks.

Die verskillende aspekte op die literêre en historiese lees van $\mathrm{Ou}$ Testamentiese tekste is oorbekend. ' $n$ Herhaling hiervan is onnodig. Om 'n lys daarvan op te noem, loop jy altyd die gevaar om sommige aspekte uit te laat of sekeres daarvan oor of onder te beklemtoon. By wyse van illustrasie noem ek slegs 'n paar aspekte van die leesproses om die waarde van 'n literêr-historiese lees van die Ou Testament te beklemtoon.

\subsubsection{Teksafbakening}

Om tot sinvolle navorsingsresultate te $\mathrm{kom}$, is dit nodig om met afgebakende tekseenhede te werk wat 'n bepaalde kohesie in vorm en inhoud reflekteer. Deur middel van formele en inhoudelike kriteria kan eiesoortige en selfstandige tekseenhede afgebaken en geïdentifiseer word. Dit geld vir alle tekste van die Bybel.

\subsubsection{Tekskritiek}

Die teks van die Massoretiese tradisie - soos verskyn in die Biblia Hebraica Stuttgartensia - is meestal die uitgangspunt en objek van eksegetiese analise ${ }^{41}$. Die teksuitgawe van Biblia Hebraica Kittel of ander teksedisies is egter nie hierby uitgesluit nie. 
Die doel van tekskritiek is al beskryf om "Textfehler auszumerzen und ursprüngliche Lesarten wiederherzustellen" 42 of dit kan gerig wees op "understanding it (die teks) within a wider textual context"43. Of 'n sogenaamde "oorspronklike teks" bestaan het, is hoogs te betwyfel. Daarvoor skiet ons kennis tekort en stel tekste/teksvariante feitlik onoorkombare probleme. Vertalings en ander tekstradisies se funksionering binne verskillende kontekste reflekteer, soos die in die geval van die Massoretiese teks, 'n bepaalde selfstandigheid.

Met die tekskritiese arbeid skep die eksegeet dus sy eie sogenaamde Endgestalt van die teks ten einde die betekenis daarvan vas te stel. Dit wys hom/haar ook op die probleme wat deur die teksoorlewering totstand kom.

\subsubsection{Vormanalise}

Die vormanalise het ten doel om die struktuur en opbou van elke teks bloot te lê ten einde die teks se betekenis te bepaal, vername begrippe te lokaliseer en die literêre funksie daarvan te bepaal.

Met inagneming van morfologiese, sintaktiese, stilistiese en semantiese kriteria, kan elke teks in kleiner eenhede ingedeel word. Poëtiese tekste kan in stiges, strofes en stansas (strofe-eenhede) ${ }^{44}$ onderverdeel word. Narratiewe tekste word in soortgelyke literêre eenhede ingedeel.

Met behulp van intra-tekstuele en ekstra-tekstuele relasies ${ }^{45}$ word kohesiebinding, wat die ('n) struktuur blootlê, aangedui. Die wisselwerking van relasies op klank-, woord-, sins- en struktuurvlak dra tot die ontplooiing van semantiese kategorieë in die teks by.

\subsubsection{Tradisiekritiek}

Onder hierdie eksegetiese faset word geykte Ou-Testamentiese tradisiemateriaal geïdentifiseer en die literêre funksie daarvan binne die gegewe teks se struktuur bepaal.

Die vasstelling van geykte tradisies en motiewe (beelde, temas en trekke) ${ }^{46}$ reflekteer die diakroniese bearbeiding van die teks. Die uitdaging word daarmee aan die eksegeet gerig om die inhoud en funksie van hierdie motiewe - wat alreeds 'n diakronies-geykte semantiese inhoud bevat - binne die nuwe konteks van elke teks te bepaal.

\subsubsection{Verskeie ander aspekte}

Verskeie aspekte wat die literêr-historiese lees van tekste aanvul, kan hierby genoem word. Literêre aspekte sluit nog die bepaling van die genre of Gattung van die teks in (deur middel van Formkritik); die bepaling van die teks se breër konteks(te) binne die gegewe Bybelboek of kanon asook 
die retoriese funksie van sekere literêre duiders binne die teks help om tekste verantwoordelik binne literêre verband te lees.

Daarbenewens ondersoek die historiese aspekte nog die mondelinge oorlewering van die teks; die redaksionele byvoegings en veranderings wys hoe die teks in verskillende kontekste weer gebruik en herinterpreteer is (vgl die Redaksiekritiek); die teks se oorspronklike Sitz im Leben of funksie binne die kultus of antieke liturgie lewer 'n verdere bydrae om die teks binne sy vroeë ontstaansituasie(s) te verstaan.

Op hierdie wyse komplementeer die sinkroniese en diakroniese invalshoeke op die lees van die Ou Testament mekaar. Vir die eksegeet en Bybelleser bied dit 'n geïntegreerde visie op die teks. Dan kan die eksegeet selfs speels omgaan om sy/haar eie voorveronderstellings aan die teks te toets. Kontekstuele uitgangspunte en vrae kan dan die "bril" wees waarmee hy/sy die teks lees.

\section{GEVOLGTREKKING}

Vir my is dit duidelik dat die literêr-historiese benadering 'n rigtinggewende invloed op die eksegetiese en hermeneutiese debat moet uitoefen. Dit laat reg geskied aan sowel die sinkroniese as diakroniese ontleding van enige Ou Testamentiese teks. In hierdie opsig is dit 'n oorkoepelende en komprehensiewe invalhoek op die teks.

Die greep wat Suid-Afrikaanse eksegete dus op die literêre, narratiewe en retoriese ontvouing van tekste vertoon, moet nie verslap word nie. Maar daar is op die oomblik 'n wanbalans. Veelmeer sal Bybeluitleg in die lig van historiese gesigspunte uitgelê en verstaan moet word. Die historiese bewussyn sal in Suid Afrika drasties opgeskerp en ontwikkel moet word.

'n Literêr-histories benadering tot eksegese hou die voordeel in dat:

1 literêre dimensies van die teks tot hulle reg kom in die bepaling van 'n teks se betekenis;

2 historiese dimensies binne en agter die teks verreken word in die proses om die teks te verstaan en uit te lê;

3 voorveronderstellings en kontekstuele gegewenheid(e) van die eksegeet as deel van die historiese verstaan in die eksegetiese proses erken word.

4 dit as oorkoepelende benadering na 'n omvattende en holistiese uitleg van Bybelse tekste streef. 


\section{NOTAS:}

1 Vergelyk J H le Roux, A story of two ways. Thirty years of Old Testament scholarship in South Africa, Pretoria 1993; J A Loader, "Die weg van die Here in die woestyn oftewel God se grootpad in die wildernis: Oor 'n Story of two ways", Skrif en Kerk 15/2 (1994), 391-413; I J J Spangenberg, "Paradigmaverandering in die Bybelwetenskappe. Bydrae tot die gesprek tussen die Bybelwetenskappe en Sistematiese Teologie", Religion and Theology 1/2 (1994), 144184; I J J Spangenberg, "Kritiese realisme, die Bybel, die Gereformeerde Belydenisskrifte en die Christelike geloof", Religion and Theology 2 (1995), 191-205; L C Jonker, Exclusivity and variety. Perpectives on multidimentional exegesis, Kampen 1996; J H le roux, "Eksegese is 'n spel”, Acta Theologica 1 (1996), 41-56; W S Prinsloo, "Eksegese is 'n spel (sonder reëls?)", Acta Theologica 2 (1996), 21-33; L C Jonker, "Bridging the gap between Bible readers and 'proffessional' exegetes'", OTE 10/1 (1997), 69-83; H J M van Deventer, "Oor paaie, sirkels en waarhede: 'n Bydrae met betrekking tot die huidige hermeneutiese gesprek", Acta Theologica 1 (1998), 77-95; L C Jonker, "'Interpretasierigting' as eksegetiese hulp. Rut in wyer konteks", Acta Theologia 1 (1999), 37-57. Hierbenewens gee talle Ou Testamentici in 'n volledige spesiale uitgawe van Old Testament Essays 7/4 (1994) aandag aan die literêre (P Nel, J Coetzee, W S Prinsloo, M Oosthuizen, P J van Dyk, J Hunter, B C Lategan) en historiese (P A Krüger, W Boshoff, D Pienaar, J P J Olivier, E H Scheffler, W Domeris, G Wittenberg, S D Snyman, H Krüger, J $\mathrm{H}$ le Roux) lees van Ou Testamentiese tekste.

2 G T M Prinsloo, 'n Literêr eksegetiese analise van die boek Habakuk (Ongepubliseerde DD-proefskrif, Pretoria 1989, 44 ev, gee 'n volledige oorsig oor die belangrikste metodologiese uitgangspunte en hulle manifestasiegestaltes. Vergelyk ook P J Nel, "A critical perspective on Old Testament exegetical metholdology", OTE 2/3 (1989), 64-74.

3 J Barton, Reading the Old Testament. Method in Biblical Study, Philadelphia 1984, 201.

$4 \quad \mathrm{H}$ Barth \& O H Steck, Exegese des alten Testaments. Leitfaden der Methodik, Neukirchen-Vluyn 198912, reflekteer die kulminering van hierdie metode(s). Vergelyk ook W S Prinsloo, "Die histories-kritiese metode(s) in perspektief", Skrif en Kerk 9/2 (1988), 196-206.

5 B C Lategan, "Inleidende opmerkings oor resepsieteorie en die uitleg van Bybelse materiaal", NGTT 28 (1987), 114; B C Lategan, "Some implications of reception theory for the reading of Old Testament texts", OTE 7/4 (1994), 105-112.

6 P J Botha, "Resepsieteorie: Konkurrent of komplement van teksimmanente eksegese?", Skrif en Kerk 10/2 (1989), 113-127.

7 E H Scheffler, "The psychological approach to the (Hebrew) Bible", OTE 7/4 (1994), 148-159.

8 W Domeris, "Anthropological and socio-historical readings of the Old Testament", OTE 7/4 (1994), 160-166.

9 G Wittenberg, "deological/materialist approach to the Old Testament", OTE 7/4 (1994), 167-172. 
S D Snyman, "Political reading as a means of understanding", OTE 7/4 (1994), 173-180.

11 M Odendaal, "A Feminist understanding of the Old Testament", OTE 7/4 (1994), 254-258.

12 S P Abrahams, "A black theological perspective on the Old Testament", OTE 7/4 (1994), 244-253.

13 Vergelyk F E Deist, "Ou-Testamentiese eksegete en algemene literatuurwetenskap", NGTT 14/1 (1973), 75-81; F E Deist, "Ope vrae aan die diskoeranalise", NGTT 19/4 (1978), 260-271; F E Deist, "Again: method(s): Reflections on text and reality", OTE 1 (1983), 73-88; F E Deist, "Gekontroleerde" eksegese en/of "kreatiewe uitleg", HTS 44/1 (1988), 39-54; F E Deist, "Eksegese as 'leeskompetensie': Oor onderrig in Skrifuitleg", NGTT 30/1 (1989), 56-63; J A Loader, "Gedagtes oor gekontroleerde eksegese", HTS 34 (1978), 1-40; J A Loader, "De structuuranalytische methoden" In: Van der Woude, A S (red), Inleiding tot de Studie van het Oude Testament, 1986, 128142; W S Prinsloo, "Die metodiek van eksegese. 'n Diskussie", NGTT 20/1 (1979), 201-223; W S Prinsloo, "Die histories-kritiese metode(s) in perspektief", Skrif en Kerk 9/2 (1988), 196-206; W S Prinsloo, "Oor eksegetiese metodes en nog wat: 'n Gesprek", HTS 46 1/2 (1990), 144-152; W S Prinsloo, "Weer eens: Eksegetiese metodes", Skrif en Kerk 13/2 (1992), 182-188.

14 J J Burden, "Poëtiese tekste". In: Deist, F E \& Vorster, W (red), Woorde wat ver kom. Die literatuur van die Ou Testament (Deel 1), Pretoria 1986a, 37-68: J J Burden, "Reconsidering parallelism in the Old Testament", OTE 4 (1986b), 141-176; PJ Botha, a w, 1989, 113-127; P J Nel, "Ou-Testamentiese Poësie. Metodologie en Perspektief”, Acta Academica 21/3 (1989a), 61-77; P J Nel, “A Critical Perspective on Old Testament Exegetical Methodology", OTE 2/3 (1989b), 64-74; G T M Prinsloo, "Analysing Old Testament Poetry: Basic issues in the contemporary exegesis", Skrif en Kerk 12/1 (1991), 64-71.

15 Le Roux, $a w, 1993$.

16 Loader, $a$ w, 1994, 391-431.

17 Vergelyk die kritiek en gebreke op dié verskillende metodes of metodefasette by Deist, aw, 1978, 265-268; Loader, $a w, 1986,129$; Nel, $a w, 1989 b, 64-74$; G T M Prinsloo, $a$ w, 1989, 50; J H le Roux, "W S Prinsloo se immanente lees van die Psalms”, NGTT (1989), 390; Le Roux, a w, 1996, 41-56.

18 W Richter, Exegese als literaturwissenschaft, Göttingen 1971, se navorsing het die insig gevestig dat literatuurwetenskap in die bedryf van Bybelse ekseges noodsaaklik is

19 N H Ridderbos, "Kenmerken der Hebreeuwse Poëzie". In: Van Grindel en andere (reds), Psalmenstudie (1991), 66-78.

20 T Collins, Line-forms in Hebrew Poetry: A Grammatical Approach to the Stylistic Study of the Hebrew Prophets, Rome 1978, 23 ev.

21 J L Kugel, The idea of Biblical poetry: Parallelism and its history, New Haven 1981, 1-58.

22 Kugel, $a w, 23$, formuleer dit met sy bekende uitspraak: " $\mathrm{A}$ is so, and what's more, B". R Alter, The art of Biblical narrative, New York 1985, 3-26, gee feitlik dieselfde inhoud aan die parallelisme as Kugel sonder om dit pertinent te definieer. W G E Watson, Classical Hebrew Poetry. A Guide to its techniques 
(JSOT Suppl 26), Sheffield 1984, 117, beskryf die parallelisme as die relasie van volledige kongruensie. Vergelyk P J Nel, $a w, 1989 \mathrm{a}, 63 \mathrm{ev}$. vir 'n opsommende geheelbeeld.

23 A Berlin, The dynamics of biblical parallelism, Bloomington 1985, $140 \mathrm{ev}$.

24 W T W Cloete, Versification and Syntax in Jeremiah 2-25. Syntactical constraints in Hebrew colometry, Stellenbosch 1978, 5, het vroeg reeds die vernaamste redes vir die botsende standpunte hieroor weergegee.

$25 \quad$ Kugel, $a w, 1981,301$.

26 O Loretz, “Die Psalmen II", AOAT 2 07/2 (1979), 7-12; O Loretz, "Die Ugaritistik in der Psalmeninterpretation (11)". UF 17 (1986), 213-217.

27 D N Freedman, "Acrostics and Metrics in Hebrew Poetry", HTR 65 (1972), 367-392; D N Freedman, "Acrostic Poems in the Hebrew Bible: Alphabetic and otherwise", CBQ 48 (1986), 408-431.

28 L Alonso Schökel, A Manual of Hebrew Poetics, Rome 1988.

29 M O'Connor, Hebrew Verse Structure, Winona Lake 1980, 54-166.

30 G Wanke se mening is duidelik in G Fohrer (ea), Exegese des Alten Testaments, Heidelberg 1983, 64-83.

31 Watson, $a w, 16$.

32 V Robbins, Exploring the texture of texts: A guide to socio-rhetorical interpretation, Valley Forge 1996.

33 J H le Roux, "Historical criticism - the end of the road?", OTE 7/4 (1994), 1994.

34 G T M Prinsloo, "Die rol van Ou Testament Teologie in die prediking”, Skrif en Kerk, $15 / 2$ (1994), 364.

35 M Noth, Geschichte Israels (WMANT 51). Göttingen $1986^{10}$

$36 \mathrm{R}$ Albertz, A history of Old Testament religion in the Old Testament period Two volumes (Translated by J Bowden). Philadelphia 1994.

37 K van der Toorn, Family Religion in Babylonia, Syria and Israel. Continuity and change in the forms of religious life, Leiden 1996.

$38 \mathrm{~J} \mathrm{C}$ De Moor, The rise of Yahwism. The roots of Israelite monotheism (BETL XCI) Leuven 1997.

39 Hierdie insig het in my gesprekke met talle Europese eksegete na vore gekom. Die ervaring van my leermeester Prinsloo, $a w, 1992,182$, bevestig dit.

40 Voorbeelde hiervan is duidelik te bespeur by Richter, $a w, 1971$; Fohrer, $a w$, 1983; Watson, $a w, 1986$ en Barth \& Steck, $a w, 1989^{12}$. Binne die SuidAfrikaanse konteks volg verskeie eksegete, na gelang van hulle eie persoonlike uitgangspunte, 'n omvattende benadering. Vergelyk Loader, $a w, 1978,3$ : "pluralisme van metodes"; W S Prinsloo, $a w, 1979,204$, waarsku teen "metodemonisme"; J H Coetzee, Die spanning tussen God se "verborge wees" en sy "ingrype om te red". 'n Eksegetiese ondersoek na 'n aantal Klaagpsalms (DD-Proefskrif), Pretoria 1986, 15: “'n verskeidenheid van metodiese aspekte". Sy benadering van "close reading" in $\mathrm{J} H$ Coetzee, "Close reading of the Bible" OTE Suppl 7/4 (1994), 72-77, as "a comprehensive term for different approaches to texts” bevestig sy uitgangspunt; P J Botha, Die teologiese funksie van die Torah-woordveld in die driehoeksverhouding Jahwe-vrome-vyand in Psalm 119 (DD-Proefskrif), Pretoria 1986, 18: "pluralisme van metodes"; G T M Prinsloo, $a w, 1989,56$ en G T M Prinsloo, $a w, 1991,67$, praat van 'n 
"omvattende benadering". Ook H Viviers, 'n Teksimmanente ondersoek na die samestelling van die Ma'alot Psalms (Pss 120-134), Pretoria 1990, 4, onderskryf 'n "komplementêre metode". Ten spyte daarvan dat P J Nel, $a$ w, $1989 \mathrm{~b}, 71$, die bogenoemde benadering as "the (eie kursivering) South African discourse analysis" tipeer en dit beoordeel as "a theoretically impoverished mixture of methods", kan hy nie anders nie as om in sy eie literêr-teoretiese konstruksie en struktureel-semantiese benadering tot Hebreeuse poësie ook vir "'n omvattende wyse" van analise te kies nie. Sien Nel, $a$ w, 1989a, 71. Meer onlangs praat L C Jonker, $a w, 1999,55$, ook daarvan dat "meer metodes noodwendig saam ingespan moet word in die proses van interpratasie. Daarmee word die multi-dimensionele aard van die Bybeltekste... beter verreken.

41 Van F E Deist, "Is die Massoretiese teks die Ou Testament", Skrif en Kerk 10/1 (1989), 9-20, se kritiek op die voorkeur wat normaalweg aan die Massoretiese teks verleen word asook die verarmende effek wat die verwaarlosing van ander tekstradisies met hierdie keuse tot gevolg het, word ernstig geneem. Tekskritiek is egter 'n uiters gespesialiseerde wetenskap en die perspektiewe waarin verskillende tradisies met mekaar vergelyk word, moet ook in die eksegetiese proses verreken word.

42 E Würthwein, Der Text des Alten Testaments. Eine Einführung in die Biblia Hebraica, Stuttgart 19734, 103; FE Deist, Towards the text of the Old Testament, Pretoria 1978, 11 en Fohrer, $a$ w, 1983, 24.

43 F E Deist, Witnesses to the Old Testament. The literature of the Old Testament (Vol 5), Kaapstad 1988, 1.

44 Dit reflekteer 'n geringe afwyking van die heersende praktyk om poëtiese tekste in stiges, strofes en stansas te verdeel - vergelyk P van der Lugt, Strofische structuren in de Bybels-Hebreewse Poezie, Kampen 1980, $171 \mathrm{ev,} 220$ en Watson, $a w, 12-13$, vir die definisies daarvan.

45 Op voetspoor van I Gräbe gee G T M Prinsloo, $a w, 1989,61$, en ook W S Prinsloo, "Psalm 145: Loof Jahwe van A tot Z", In die Skriflig 25/4 (1991), inhoud aan hierdie begrippe. Intratekstuele relasies is die netwerk van bindinge wat op verskillende taalvlakke binne 'n spesifieke teks bestaan, terwyl ekstratekstuele relasies verstaan kan word as die verwantskappe wat tussen verskillende tekste van die Ou Testament op literêre of nie-literêre (onder andere datering, outeur en genre) vlak bestaan.

46 Hier word van Fohrer, $a w, 1983,105,111-113$, se definisie of begripsinhoud van die begrippe geykte tradisie, geykte motief en geykte beeld uitgegaan. 